\begin{tabular}{lllllllll}
$\mathbf{A}$ & $\mathbf{R}$ & $\mathbf{T}$ & $\mathbf{Y}$ & $\mathbf{K}$ & $\mathbf{U}$ & $\mathbf{L}$ & $\mathbf{Y}$ \\
\hline
\end{tabular}

ROCZNIKI HUMANISTYCZNE

Tom LXII, zeszyt $9 \quad-\quad 2014$

IRENA KAŁUŻYŃSKA

\title{
AKSJOLOGIA \\ A CHIŃSKIE TRADYCYJNE IMIONA KOBIET
}

\author{
AXIOLOGY AND TRADITIONAL CHINESE \\ NAMES OF WOMEN
}

\begin{abstract}
The paper discusses the group of Chinese traditional female names containing lexemes denoting moral, mental and behavioural features of women. The features mentioned are related to human values distinguished by philosophers and psychologists in the domain of axiology, i.e. the theory of value. The typology of values elaborated by M. Rokeach in 1973 serves as a framework for the research. The research material contains 1050 lexemes evidenced in 2931 standard personal names of Chinese women. The lexemes denoting female values stand for $27 \%$ of all lexemes analysed, and occur in 1600 names. Personal names denoting the values reveal to some extent the system of values preferred in traditional China, and seem to be important for the further studies in the domain of axiology.
\end{abstract}

Aksjologia to nauka o wartościach czy też ogólna teoria wartościowania. Początków tej dyscypliny należy szukać u Sokratesa (dobro absolutne, praktykowanie dobra, szukanie tkwiącej w człowieku wiedzy o tym, co dobre), Platona (istnienie wartości dobra, piękna, prawdy jako samodzielnych bytów czy idei, transcendentnych wobec człowieka; dobro pierwszą zasadą i ostatecznym celem świata), Arystotelesa (dobro jest tym, co zgodne z naturą; szczęście jako dobro ostateczne, środkiem osiągania cnót moralnych jest

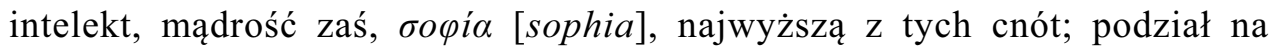
dobra wewnętrzne ,same w sobie” i dobra zewnętrzne, związane z użytecznością, instrumentalne) i innych filozofów starożytnych. Dla jej rozwoju

IRENA KAŁUŻYŃSKA - Zakład Sinologii na Wydziale Orientalistycznym Uniwersytetu Warszawskiego; adres do korespondencji - e-mail: i.s.kaluzynska@uw.edu.pl 
w epoce nowożytnej bardzo istotny był wkład umysłowy Kanta. Zainteresowanie naturą i systemem wartości pojawiło się zwłaszcza na przełomie XIX i XX wieku i trwa do dziś. Nazwiska istotne dla rozwoju aksjologii to m.in. Brentano, Meinong, Ehrenfels, Dewey, Moore, Perry, Scheler, Hartmann, Rokeach, w Polsce: Ossowska, Znamierowski, Ingarden, Tatarkiewicz i wielu innych ${ }^{1}$.

Sam termin ,aksjologia” pojawił się najpierw w wersji francuskiej axio-

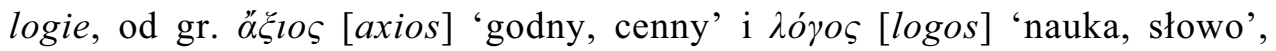
stąd 'nauka o tym, co cenne, godne'. Został użyty po raz pierwszy przez filozofa P. Lapie w 1902 r. $^{2}$

W literaturze filozoficznej wartości to generalnie przedmioty i przekonania o nienormatywnym charakterze, determinujące podobne przeżycia psychiczne i działania jednostek. W rozumieniu kulturowym wartości to powszechnie pożądane w danym społeczeństwie przedmioty o symbolicznym charakterze oraz powszechnie akceptowalne sądy egzystencjalno-normatywne (tzw. orientacje wartościujące). Wartość to m.in. przekonanie, że pewne ukierunkowanie postępowania lub cel istnienia są indywidualnie lub społecznie lepsze od przeciwstawnych. Ludzkie wartości traktowane są jako podstawa kultury duchowej. Wartości należą do określonego systemu kulturowego, którego integralną częścią jest zbiór norm i wartości, czyli system aksjonormatywny, obejmujący zwyczaje, moralność, prawo oraz poczucie estetyki (albo też panującą modę).

Badania nad systemem i językiem wartości mieszczą się współcześnie w ramach językoznawstwa kognitywnego, które uznaje język za formę poznania świata zewnętrznego. Badając język, można odkryć, w jaki sposób człowiek postrzega i konceptualizuje świat, a także w jaki sposób go wartościuje. Językowy obraz świata to pewien zespół sądów mniej lub bardziej utrwalonych $\mathrm{w}$ języku, zawartych w znaczeniach wyrazów lub przez nie implikowanych, orzekający o cechach i sposobach istnienia obiektów świata pozajęzykowego. Problem wyrażania wartości poprzez język pojawia się w literaturze językoznawczej szczególnie często od połowy lat siedemdziesiątych XX wieku ${ }^{3}$

\footnotetext{
${ }^{1}$ Jadwiga PuZYNina, Język wartości, Warszawa: Wydawnictwo Naukowe PWN, 1992, s. 19-43.

${ }^{2}$ http://pl.wikipedia.org/wiki/Aksjologia

${ }^{3}$ Zob. Język w kręgu wartości. Studia semantyczne, red. Jerzy BARTMIŃSKI, Lublin: Wydawnictwo UMCS, 2003.
} 
Treści wartościujące jako składowe obrazu świata są przekazywane w języku przede wszystkim przez słownictwo. Według Jerzego Bartmińskiego „uprzywilejowaną podstawą obrazu świata jest słownictwo, stanowiące klasyfikator społecznych doświadczeń i zawierające inwentarz pojęć relewantnych egzystencjalnie, społecznie i kulturowo" ". Część zasobu leksykalnego każdego języka stanowią nazwy własne i przez to uczestniczą one w procesach wartościowania. Osobowe nazwy własne są nośnikami wartości w sensie aksjologicznym.

Badania filozofów i psychologów nad ludzkimi wartościami oraz lingwistów nad językiem wartości dostarczają narzędzi do odkrycia uniwersalnych lub typowych tylko dla danej społeczności treści aksjologicznych zawartych w nazwach własnych. Według analiz filozofów i psychologów ${ }^{5}$, utrwalonych w tzw. typologiach wartości, świat ludzkich wartości można uporządkować, dzieląc je na różne typy. Są to ${ }^{6}$ :

- wartości deklarowane, uznawane i odczuwane;

- wartości ujmowane w perspektywie egoistycznej, allocentrycznej lub socjocentrycznej;

- wartości ostateczne i instrumentalne.

Spośród wymienionych typów podstawą czy też odniesieniem dla wielu badań, w tym onomastycznych, usiłujących odtworzyć świat ludzkich wartości odzwierciedlony w nazwach własnych, stał się podział Rokeacha, dzielący wartości na ostateczne i instrumentalne ${ }^{7}$. W tym podziale wartości

${ }^{4}$ JERZY BARTMIŃSKI, Językowe podstawy obrazu świata, Lublin: Wydawnictwo UMCS, 2006, s. 13.

${ }^{5}$ Zob. Milton Rokeach, The Nature of Human Values, New York: The Free Press, 1973; PuZYNINA, Język wartości.

${ }^{6}$ PuZYNina, Język wartości, s. 29-43.

${ }^{7}$ Zob. ZOFIA KaLETA, Świat ludzkich wartości odzwierciedlony w nazwach własnych (nazwiska zachodnioeuropejskie i stowiańskie), „Slavia Occidentalis” 52 (1994), s. 28-52; TAż, Świat ludzkich wartości odzwierciedlony w nazwach własnych osób (semantyka imion staropolskich z członami -mir, -mysł, -sław na tle indoeuropejskim), „Slavia Occidentalis” 53 (1995), s. 7-13; TAŻ, Świat ludzkich wartości odzwierciedlony w nazwach własnych osób (Imiona staropolskie z członem dobr(o) na tle indoeuropejskim i wartości w nich wyrażone, „Slavia Occidentalis” 54 (1997), s. 29-38; TAŻ, Wartości i antywartości w staropolskich odapelatywnych nazwach osób, w: Nazwy wlasne a kultura, red. Zofia Kaleta, (Prace Slawistyczne 115), Warszawa: Slawistyczny Ośrodek Wydawniczy, 2003, s. 21-48; TAŻ, Human values as reflected in IndoEuropean compound-names, „Onoma” (Leuven) 34 (1998-1999), s. 83-93; TAŻ, Values and antivalues in nicknames, w: Proceedings of the 21st International Congress of Onomastic Sciences, 2006, s. 145-155; Ewa RZETELSKA-FELESZKo, $W$ świecie nazw wlasnych, Warszawa-Kraków: TNW, 2006, s. 9-34, Maria MALEC, Imię w polskiej antoponimii i kulturze, Kraków: DWN, 2001, s. 65-97. 
ostateczne (terminal values), czyli absolutne, podstawowe, autoteliczne, wartości same w sobie, czy też cele człowieka same w sobie, są pożądanymi stanami rzeczy, do których człowiek dąży. Rokeach ${ }^{8}$ wylicza osiemnaście wartości ostatecznych. W wolnym tłumaczeniu są to:

(1) życie szczęśliwe, wygodne, dostatnie (comfortable, prosperous life),

(2) równość, braterstwo, równe możliwości (equality, brotherhood and equal opportunity for all),

(3) życie aktywne, pasjonujące (exciting, stimulating, active life),

(4) bezpieczeństwo rodzinne, opieka nad tymi, których się kocha (family security - taking care of loved ones),

(5) wolność, niezależność, wolny wybór (freedom - independence and free choice),

(6) zdrowie fizyczne i psychiczne (health - physical and mental wellbeing),

(7) harmonia wewnętrzna (inner harmony - freedom for inner conflict),

(8) dojrzała miłość, bliskość seksualna i duchowa (mature love - sexual and spiritual intimacy),

(9) bezpieczeństwo narodowe (national security - protection from attack),

(10) przyjemność, radość, swobodne życie (pleasure - enjoyable, leisurely life),

(11) zbawienie, życie wieczne (salvation - saved, eternal life),

(12) szacunek dla siebie, dobra samoocena (self-respect, self-esteem),

(13) poczucie spełnienia, dokonań (sense of accomplishment - a lasting contribution),

(14) uznanie społeczne, szacunek (social recognition - respect and admiration),

(15) prawdziwa przyjaźń, koleżeństwo (true friendship - close companionship),

(16) mądrość, dojrzałe rozumienie życia (wisdom - mature understanding of life),

(17) pokój na świecie (world at peace - world free of war and conflict),

(18) świat piękna - piekno przyrody, sztuki (world of beauty - beauty of nature and arts).

Druga grupa wartości, szczególnie ważna dla niniejszego artykułu, to wartości instrumentalne (instrumental values), uzualne, służebne, pragmatyczne, których uzyskanie służy pośrednio osiągnięciu wartości absolutnych. Stanowią je przede wszystkim cechy osobowości, zachowania i postawy człowieka pożądane w życiu rodzinnym i społecznym. Są one wyrażane w formie przymiotnikowej, stąd czasem wątpliwości, czy dotyczą postępo-

\footnotetext{
${ }^{8}$ RoKeACH, The Nature of Human Values, s. 28.
} 
wania, czy cech osobowości. Według Rokeacha ${ }^{9}$ wyliczyć można osiemnaście wartości instrumentalnych. W wolnym tłumaczeniu są one następujące:

(1) ambitny, mający aspiracje, pracowity (ambitious - hardworking and aspiring),

(2) mający otwartość umysłową, myślący (broad-minded, open-minded),

(3) zdolny, kompetentny i efektywny (capable - competent, effective),

(4) czysty, schludny (clean - neat and tidy),

(5) odważny, broniący swych ideałów (courageous - standing up for his beliefs),

(6) przebaczający, skłonny do wybaczania (forgiving - willing to pardon others),

(7) będący pomocnym, usłużnym, pracujący dla dobra innych (helpful working for the welfare of others),

(8) szczery, uczciwy (honest - sincere and truthful),

(9) kreatywny, śmiały (imaginative - daring and creative),

(10) niezależny, samowystarczalny (independent - self-reliant, self-sufficient),

(11) inteligentny i refleksyjny (intellectual - intelligent and reflective),

(12) logiczny, konsekwentny, racjonalny (logical - consistent, rational),

(13) kochający, uczuciowy, czuły (loving - affectionate and tender),

(14) lojalny (loyal - faithful to friends or the group),

(15) posłuszny, obowiązkowy, pełen szacunku dla innych (obedient - dutiful, respectful)

(16) uprzejmy, grzeczny, z dobrymi manierami (polite - courteous and wellmannered),

(17) odpowiedzialny, niezawodny, godny zaufania (responsible - dependable and reliable),

(18) zdyscyplinowany, opanowany, powściągliwy (self-controlled - restrained, self-disciplined).

Wartościowanie może być pozytywne - gdy to, co się ma lub do czego się dąży, uznawane jest za dobre, lub negatywne - gdy jest niepożądane, uważane za zło. Niemal każda z wartości ma swój znak ujemny i dodatni, co odzwierciedla się w języku: mądry - głupi, piękny - brzydki itp.

W wielu kulturach, m.in. chińskiej, afrykańskiej, żydowskiej, a także dawnej kulturze Słowian, rekonstruowanej z materiałów językowych, obrzędowych czy folklorystycznych, wierzono, że imię tworzy i formuje człowieka, uważano związek łączący imię z nazywanym człowiekiem jako ści-

\footnotetext{
${ }^{9}$ Tamże s. 28.
} 
sły. Nadanie imienia stanowiło ważny akt antropologiczny o charakterze sakralnym, nadający nowo narodzonemu status człowieka.

Nazwy własne osobowe, antroponimy, pełnią w języku specyficzne funkcje. Z językoznawczego punktu widzenia ich funkcją prymarną, tj. funkcją, która czyni je nazwami i stanowi powód ich istnienia we wszystkich językach świata, jest identyfikacja ludzi. Funkcja identyfikacyjna to inaczej funkcja onomastyczna lub znaczenie onomastyczne nazwy. Podstawowe dla antroponimu jest zatem znaczenie onomastyczne, natomiast znaczenie leksykalne jest nieistotne. Przypisanie nazwy osobie jest arbitralne: każda nazwa jest pod tym względem odpowiednia. Nazwy osobowe to jednak nie tylko konkretne formy językowe, ale także pewne fakty socjokulturowe. Antroponimy powstawały i powstają $\mathrm{w}$ konkretnym języku w powiązaniu z pozajęzykowymi zjawiskami kulturowymi. Na ich formę i funkcje miały i mają wpływ cechy języka, charakterystyka danej społeczności, wspólnoty językowej i kulturowej na poszczególnych etapach jej rozwoju. Dlatego, nawet jeśli nazwy osobowe jako nazwy nie muszą pełnić żadnych dodatkowych funkcji oprócz funkcji identyfikacyjnej, niektóre społeczeństwa przykładają znaczną wagę do innych funkcji imion, związanych przede wszystkim z ich semantyczną transparencją, czyli ich znaczeniem leksykalnym, a właściwie znaczeniem leksykalnym wyrazów czy elementów je tworzących jako będących semantycznie umotywowanymi. Generalnie zakłada się, co potwierdzają świadectwa historyczne, że w większości systemów nazewniczych imiona ludzi były pierwotnie semantycznie transparentne jako formy derywowane od apelatywnych jednostek leksykalnych konkretnych języków. Apelatywy stawały się antroponimami z chwilą, gdy ich wartością podstawową przestały być pewne klasy przejawów rzeczywistości pozajęzykowej, a stali się nią pojedynczy członkowie społeczności. Zakres ogólny, obejmujący klasę desygnatów, zmienił się więc na zakres jednostkowy, a znaczący apelatyw stał się identyfikującą nazwą własną. Znaczenie leksykalne imion jest szczególnie ważne w społeczeństwach, które nie traktują nazw tylko jako „etykietek” odnoszących się do osób, ale uważających je za bardzo istotną część ich nosicieli, podstawę ich tożsamości. W tych społeczeństwach zazwyczaj nie ma ustalonej urzędowo listy imion, lecz są one tworzone czy wybierane ze szczególną uwagą ze względu na znaczenie leksykalne użytych jednostek językowych, a także na ich znaczenia asocjacyjne ${ }^{10}$.

${ }^{10}$ Zob. Irena KAŁuŻYŃSKA, Semantically transparent given names of the Han nation, w: China Past and Present, red. MARCIN JACOBY i in., Warszawa: WUW, 2010, s. 125-134. 
Przekonanie, że imię jest związane z losem człowieka, wyrażają dawne i współczesne chińskie imiona życzące, odzwierciedlające wiarę w magiczną sferę rzeczywistości, na którą można wpływać za pomocą języka. Imię stanowi pewien rodzaj magicznego zaklęcia. Zawarte w jego treści życzenie, wyrażane atrybutywnie czy w sposób metaforyczny lub metonimiczny, ma się spełnić w życiu nosiciela imienia. W treści imienia zawierano zazwyczaj to, co uważano za najbardziej wartościowe w życiu człowieka, licząc, że nosiciel imienia, dzięki przyjaznym siłom duchowym, osiągnie przez imię pożądany stan czy cechy (moralne, intelektualne, estetyczne). Imiona ukazują zatem różne elementy kultury duchowej społeczeństwa, jego wierzenia, mentalność i system wyznawanych wartości.

Sfera aksjologiczna $\mathrm{w}$ onomastyce to właśnie pojmowanie imienia jako wartości duchowej i dobra rodzinnego, a także jako nośnika innych wartości ważnych dla jego nosiciela i całej rodziny czy społeczności. Imiona nadawane ludziom, a więc i motywacje dawców imion, mogą mieć źródło w wartościach materialnych lub duchowych, intelektualnych lub uczuciowych, moralnych lub estetycznych. Mogą to być wartości powszechne w danym społeczeństwie, uwarunkowane historycznie, lub też wartości uniwersalne, wspólne, niezależnie od epoki i rodzaju cywilizacji.

System imion chińskich jest językowym wytworem określonego sposobu postrzegania i wartościowania rzeczywistości, a przede wszystkim innych ludzi, charakterystycznym dla chińskiej wspólnoty językowo-kulturowej, mającej własne wyuczone wzory i standardy zachowań. Imiona chińskie odzwierciedlają w pewnej mierze społeczne i kulturowe warunki panujące w okresie ich powstania, w tym różne kulturowe oczekiwania względem kobiet w patriarchalnym społeczeństwie.

Generalnie niski status kobiety w dawnych Chinach, zarówno w rodzinie, jak i społeczeństwie, dokumentują liczne teksty historyczne i literackie. Normy życia nakreślił tam konfucjanizm, przydzielający kobiecie pozycję podrzędną w stosunku do mężczyzny. Obowiązywało ją podporządkowanie ojcu przed ślubem, mężowi po ślubie, a synowi we wdowieństwie. Nie była osobą samodzielną, lecz dodatkiem do mężczyzny. Kobieta w Chinach była określana przede wszystkim jako shūnü 淑女 'wdzięczna córka', liángqì 良妻 'dobra żona' i xiànmŭ 賢母 'oddana matka'11.

${ }^{11}$ Kang-Hu KIAng, Chinese Civilization. An Introduction to Sinology, Szanghaj: Chung Hwa Book Co., 1935, s. 224-225; Hung-MING Ku, The Spirit of Chinese people, Pekin: The Peking Daily News, 1915, s. 79. 
Obraz idealnej kobiety chińskiej według zasad etyki konfucjańskiej wywodził się z idei, że kobiety są istotami tak odmiennymi od mężczyzn, jak różni się Niebo od Ziemi, jak działająca w przyrodzie siła yáng 陽 (jasna, pozytywna, aktywna, męska) od siły yīn 陰 (ciemnej, negatywnej, biernej, żeńskiej), że występuje naturalny podział ról na męskie i kobiece, stąd kobiety powinny pielęgnować cnoty właściwe ich naturze i odpowiednie dla ich roli. Etyka konfucjańska wymagała od kobiet kultywowania cnót im właściwych, przede wszystkim ,czterech cnót”, czyli fùdé 婦德 'kobieca cnota (charakter)', fúyán 婦言 'kobieca mowa', füróng 婦容 'kobiece zachowanie czy wygląd' i fügōng 婦功 'kobieca praca' ${ }^{12}$. Według wyjaśnień, kobieca cnota czy charakter to skromność, uprzejmość, grzeczność, czystość moralna, zdyscyplinowanie, stałość, spokój. Kobieca mowa to wiedza, kiedy należy mówić, a kiedy milczeć, odpowiedni dobór słów, pewne wyrafinowanie i elokwencja. Kobiecy wygląd czy zachowanie to nie tylko fizyczna uroda, ale przede wszystkim czystość osobista i nienaganny strój. Kobieca praca nie wymaga szczególnych umiejętności czy talentu, lecz staranności i pracowitości.

Analiza wartości kojarzonych w chińskiej kulturze $\mathrm{z}$ cechami posiadanymi przez kobiety czy też dla nich pożądanymi, zapisanymi czy odzwierciedlonymi w chińskich imionach kobiecych i porównanie ich $\mathrm{z}$ wymienionymi przez Rokeacha wartościami ostatecznymi i instrumentalnymi jest zadaniem niezwykle trudnym ze względu na pewną nieprecyzyjność tych wartości zarówno w pracy Rokeacha, jak i wieloznaczność chińskich leksemów - nośników wartości. Tym niemniej podjęto próbę dopasowania osiemnastu wymienionych wcześniej wartości instrumentalnych do wartości psychicznych (osobnicze cechy charakteru i usposobienia), moralnych, umysłowych i estetycznych wyrażanych przez leksemy występujące w chińskich imionach kobiecych. Interpretacja znaczenia wielu z tych leksemów jest subiektywna, dostosowana do założeń przeprowadzanej analizy. Są one tłumaczone głównie jako formy przymiotnikowe rodzaju żeńskiego.

Leksemy związane z wartościami kobiet zostały podzielone na kilka grup, a do nich starano się dobrać typy, które znalazły się w klasyfikacji Rokeacha dotyczącej wartości instrumentalnych. Zazwyczaj jednej obszerniejszej, nie do końca jednorodnej kategorii chińskiej odpowiada kilka klas Rokeacha.

${ }^{12}$ Liji [„,Zapisy o etykiecie”], Pekin: Shisanjing Zhushu, 1957, s. 2387; Zhouli [„Rytuały Zhou], Pekin: Shisanjing Zhushu, 1957, s. 269. 
Materiał badawczy obejmuje 3316 imion kobiet narodowości Han, z czego 2421 kobiet urodzonych do 1970 r. („słynne kobiety”) oraz 895 kobiet urodzonych w latach 1982-1986 (,studentki”). Z materiału wybrano jedynie imiona standardowe w liczbie 2931. Liczba różnych leksemów wykorzystanych w tych imionach wynosi 1050 , te same leksemy pojawiają się w różnych imionach ${ }^{13}$.

\section{LEKSEMY WYRAŻAJĄCE WARTOŚCI KOBIET \\ TAKIE JAK: DOBRA, CZUŁA, KOCHAJĄCA, UPRZEJMA, GRZECZNA, WYBACZAJĄCA}

Jest to oczywiście grupa niejednorodna, odpowiadająca w przybliżeniu trzem grupom wartości instrumentalnych Rokeacha: „(6) przebaczający, skłonny do wybaczania (forgiving - willing to pardon others), „(13) kochający, uczuciowy, czuły (loving - affectionate and tender)” oraz „(16) uprzejmy, grzeczny, z dobrymi manierami (polite - courteous and well-mannered)". Ogółem zakwalifikowano tu 22 leksemy, występujące w 140 imionach „słynnych kobiet” i 16 imionach „studentek”), m.in.:

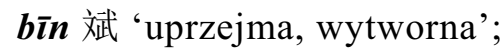

chuò 綽 'łagodna, przyjemna';

$\boldsymbol{c} \boldsymbol{i}$ 慈 ' kochająca, miłosierna, uprzejma';

$\overline{\boldsymbol{e}} \boldsymbol{n}$ 恩 'uprzejma, kochająca, wdzięczna';

hăo 好 'dobra, miła, uprzejma, ładna';

$\boldsymbol{h} \boldsymbol{e}$ 和 'uprzejma, łagodna, grzeczna';

hui 惠 'uprzejma, łagodna, wdzięczna';

liáng 良 'dobra, miłosierna, uprzejma, elegancka';

rén 仁 'dobra, miłosierna, wybaczająca, wrażliwa, cnotliwa';

róu 柔 'łagodna, czuła, uprzejma, delikatna';

shàn 善 'dobra, miła, uprzejma';

$\boldsymbol{s h} \overline{\boldsymbol{u}}$ 淑 'łagodna, uprzejma, grzeczna, wytworna, czysta';

$\boldsymbol{s h} \overline{\boldsymbol{u}}$ 舒 'lagodna, uprzejma';

xián 嫺 'łagodna, grzeczna, stateczna, spokojna';

$\boldsymbol{y} \check{\boldsymbol{a}}$ 雅 'wytworna, stosowna, przyzwoita';

$y \boldsymbol{i}$ '

\footnotetext{
${ }^{13}$ Por. Irena KatuŻyńSKA, Chinese female namings. Past and present, Warszawa: Wydawnictwo Agade, 2008, s. 26-30, 153-161.
} 


\section{LEKSEMY WYRAŻAJĄCE WARTOŚCI KOBIET \\ TAKIE JAK: SPOKOJNA, OPANOWANA, ZRÓWNOWAŻONA, ODPOWIEDZIALNA}

Ta grupa pokrywa się $\mathrm{w}$ znacznym przybliżeniu $\mathrm{z}$ wydzielonymi przez Rokeacha typami „(17) odpowiedzialny, niezawodny, godny zaufania (responsible - dependable and reliable)" i „(18) zdyscyplinowany, opanowany, powściągliwy (self-controlled - restrained, self-disciplined)". Ogółem zakwalifikowano tu 24 leksemy, występujące w 73 imionach „słynnych kobiet” i 29 imionach ,studentek”, m.in.:

$\overline{\boldsymbol{a}} \boldsymbol{n}$ 安 'spokojna, cicha, opanowana';

cháng 常 'spokojna, opanowana, stabilna';

héng 衡 'zrównoważona, stabilna, sprawiedliwa, odpowiedzialna';

jìng 静 'spokojna, stabilna, cicha';

jìng 靖 'spokojna, stabilna, cicha';

mi 宓 'spokojna, stabilna, cicha';

níng 寧 'spokojna, stabilna, cicha'

píng 平 'spokojna, opanowana; zrównoważona';

$\boldsymbol{t a ̀ i}$ 泰 'spokojna, stabilna';

wěn 稳 'stabilna, opanowana, zrównoważona'.

\section{LEKSEMY WYRAŻAJĄCE WARTOŚCI KOBIET}

TAKI JAK: CZYSTA (FIZYCZNIE I MORALNIE), UCZCIWA, SZCZERA

Ta grupa odpowiada w przybliżeniu dwóm grupom wydzielonym przez Rokeacha: „(4) czysty, schludny (clean - neat and tidy)” oraz ,(8) szczery, uczciwy (honest - sincere and truthful)", ponieważ w kulturze chińskiej czystość fizyczna jest mocno kojarzona z czytością moralną, uczciwością. Ogółem zakwalifikowano tu 36 leksemów, występujących w 189 imionach „słynnych kobiet” i 27 imionach „studentek”, m.in.:

chén 忱 'szczera, uczciwa';

chéng 誠 'szczera, uczciwa';

chún 純 'czysta, uczciwa, dobra, wytworna';

dào 道 'moralna, uczciwa';

$\boldsymbol{d e}$ 德 'cnotliwa, moralna, dobra';

$\boldsymbol{d u} \overline{\boldsymbol{a}} \boldsymbol{n}$ 端 'uczciwa, prawa, uprzejma';

fāng 方 'uczciwa, prawa'; 
jié 潔 'czysta, uczciwa, szlachetna';

$\boldsymbol{j} \boldsymbol{i e ́}$ 節 'czysta, uczciwa, moralna'

jün 均 'uczciwa, szlachetna';

lián 廉 'czysta, uczciwa, prawa, skromna';

qīng 清 'czysta, uczciwa, prawa, zrównoważona';

sù 素 'czysta, prosta, spokojna';

xián 賢 'uczciwa, cnotliwa, szlachetna, mądra'

$\boldsymbol{y} \boldsymbol{i}$ 懿 'cnotliwa, szlachetna, prawa';

$\boldsymbol{y} \boldsymbol{i}$ 義 'prawa, moralna, uczciwa';

yuán 圓 'uczciwa, taktowna, doskonała';

zhēn 貞 'uczciwa, prawa, lojalna, wierna';

zhēn 真 [眞] 'czysta, szczera, uczciwa, szlachetna';

zhèng 正 'prawa, uczciwa, szczera, czysta';

$\boldsymbol{z h}$ 直 'prawa, uczciwa, właściwa';

zhōng 忠 'prawa, uczciwa, wierna, lojalna'.

\section{LEKSEMY WYRAŻAJĄCE WARTOŚCI KOBIET}

TAKIE JAK: OBOWIĄZKOWA, LOJALNA, POSŁUSZNA, PEŁNA SZACUNKU, USŁUŻNA

Ta grupa odpowiada $\mathrm{w}$ przybliżeniu trzem grupom wydzielonym przez Rokeacha: „(7) będący pomocnym, usłużnym, pracujący dla dobra innych (helpful - working for the welfare of others)”, „(14) lojalny (loyal - faithful to friends or the group)”, „(15) posłuszny, obowiązkowy, pełen szacunku dla innych (obedient - dutiful, respectful)". Ogółem zakwalifikowano tu 15 leksemów, występujących w 27 imionach „słynnych kobiet” i 1 imieniu „studentek", m.in.:

jìng 敬 'pełna szacunku, posłuszna, usłużna, lojalna';

shùn 順 'posłuszna, poddana, lojalna, zgodna, usłużna';

$\boldsymbol{g} \overline{\boldsymbol{o n g}}$ 恭 'pełna szacunku, posłuszna, lojalna, skromna';

$\boldsymbol{l} \boldsymbol{i}$ 禮 'kurtuazyjna, pełna szacunku';

nài 耐 'cierpliwa, posłuszna, usłużna';

shèn 慎 'uważna, ostrożna, usłużna';

sì 肅 'pełna szacunku, posłuszna, czysta';

$\boldsymbol{t} \boldsymbol{i}$ 惕 'ostrożna, uważna, usłużna, pełna szacunku';

xiào 孝 'pełna szacunku wobec rodziców’. 


\section{LEKSEMY WYRAŻAJĄCE WARTOŚCI KOBIET \\ TAKIE JAK: MĄDRA, ZDOLNA, SPRAWNA, AMBITNA, PRACOWITA}

Ta grupa może odpowiadać w przybliżeniu aż sześciu typom wydzielonym przez Rokeacha: „(1) ambitny, mający aspiracje, pracowity (ambitious - hardworking and aspiring)”, „(2) mający otwartość umysłową, myślący (broad-minded, open-minded)”, „(3) zdolny, kompetentny i efektywny (capable - competent; effective)”, ,(9) kreatywny, śmiały (imaginative - daring and creative)”, „(11) inteligentny i refleksyjny (intellectual - intelligent and reflective)", „(12) logiczny, konsekwentny, racjonalny (logical - consistent, rational)". Ogółem zakwalifikowano tu 43 leksemy, występujące w 205 imionach „słynnych kobiet” i 118 imionach „studentek”, m.in.:

$\boldsymbol{c} \bar{a} \boldsymbol{i}$ 偲 'utalentowana, pilna';

cháng 長 'dobra w jakiejś dziedzinie';

cōng 聰 'mądra, bystra, zdolna';

dí 迪 'oświecona, rozumna, racjonalna';

$\boldsymbol{f} \tilde{\boldsymbol{e}} \boldsymbol{i}$ 斐 'wybitna, utalentowana literacko';

huì 慧 inteligentna, intelektualna, mądra, bystra';

jié 捷 'mądra, bystra, szybka';

juàn, jùn 隽 'wybitna, świetna';

liàng 亮 'oświecona, jasna, bystra';

líng 靈 'bystra, sprawna, kompetentna';

mào 惁 'pracowita, bystra';

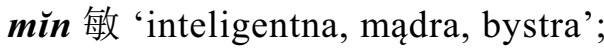

míng 明 'oświecona, jasna, inteligentna, racjonalna';

qiăo 巧 'mądra, zdolna, sprawna, kompetentna';

qín 勤 'pracowita, zapobiegliwa'

rú 儒 'uczona';

rui 蓥 'bystra, inteligentna';

shuāng 爽 'mądra, bystra, sprawna;

shuò 碩 'mądra, utalentowana';

wén 文 'zdolna literacko';

$\boldsymbol{y} \boldsymbol{i}$ 藝 'zdolna w pracach ręcznych';

y̌ng 穎 'mądra, inteligentna, wybitna';

zhé 哲 'mądra, zdolna';

$\boldsymbol{z} \boldsymbol{h}$ é 吉 'mądra, zdolna';

$\boldsymbol{z} \boldsymbol{h} \boldsymbol{i}$ 智 'mądra, zaradna, kompetentna'. 
Wśród tak wydzielonych grup wartości charakterystycznych dla imion chińskich kobiet zabrakło dwóch typów wyodrębnionych przez Rokeacha: „(5) odważny, broniący swych ideałów (courageous - standing up for his beliefs)” oraz „(10) niezależny, samowystarczalny (independent - self-reliant, self-sufficient)". Ma to niewątpliwie związek z rolą kobiet w społeczeństwie chińskim, chociaż oczywiście można znaleźć nazwy odwołujące się pośrednio też do tych wartości. Nazwy życzące są nakierowane raczej nie na teraźniejszość, ale na przyszłość. W sumie w grupach I-V wystąpiło 140 leksemów (13,4\% wszystkich leksemów z materiału badawczego), z 634 imion „słynnych kobiet” i 191 imion „studentek”.

Warto przedstawić jeszcze kilka innych grup wartości występujących w imionach chińskich kobiet, dla których nie znaleziono odpowiednich typów w klasyfikacji wartości instrumentalnych Rokeacha. Można je natomiast w pewnym zakresie powiązać z wartościami ostatecznymi (por. wyżej).

\section{LEKSEMY WYRAŻAJĄCE \\ WALORY ESTETYCZNE KOBIET}

W Chinach uważa się, że imiona kobiet powinny wyrażać pragnienie i umiłowanie piękna. Imiona dotyczące jedynie fizycznego piękna czy wyrażające jedynie walory estetyczne są niezwykle rzadkie, ponieważ wyżej niż fizyczne cenione piękno jest wewnętrzne czy duchowe. Kobieta idealna powinna łączyć piękno fizyczne z moralnym, stąd wiele terminów estetycznych ma wydźwięk moralny. Ogółem zakwalifikowano tu 43 leksemy, występujące w 276 imionach „słynnych kobiet” i 197 imionach „studentek”, m.in.:

cháng 嫦 'piękna kobieta';

$\boldsymbol{e}$ 娥 'piękna kobieta';

jīä 佳 'piękna, dobra, wspaniała, wyborna';

jiāo 嬌 'piękna, delikatna, czuła';

jìng 婧 'piękna, wiotka';

$\boldsymbol{j} \boldsymbol{u} \overline{\boldsymbol{a}} \boldsymbol{n}$ 娟 'piękna, wdzięczna, elegancka';

jùn 俊 'piękna, przystojna, wybitna';

lì 麗 'piękna, elegancka, olśniewająca';

mĕi 美 'piękna, wyborna';

miào 妙 'piękna, wspaniała, wyborna';

$\boldsymbol{n a ̀}$ 娜 'piękna kobieta';

qiàn 倩 'piękna, śliczna'; 
$\boldsymbol{s h} \overline{\boldsymbol{u}}$ 姝 'piękna kobieta, piękna';

tíng 婷 'piękna, zgrabna';

$\boldsymbol{w a} \boldsymbol{n}$ 婉 'piękna, wdzięczna, elegancka';

xiù 秀 'piękna, elegancka, wyrafinowana';

yán 妍 'piękna, doskonała';

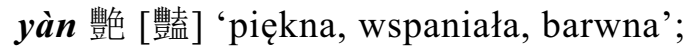

yàn 彦 'piekna, elegancka, doskonała';

$\boldsymbol{y} \boldsymbol{i}$ 儀 'piękna, czcigodna';

yīng 媖 'piękna';

yuàn 媛 'piękna kobieta';

$\boldsymbol{z} \overline{\boldsymbol{\imath}}$ 姿 'piękna'.

\section{LEKSEMY WYRAŻAJĄCE \\ ZADOWOLENIE, RADOŚĆ, WESOŁOŚĆ KOBIET}

Ogółem zakwalifikowano tu 11 leksemów, występujących w 32 imionach „słynnych kobiet” i 40 imionach „studentek”, m.in.:

$\boldsymbol{h u} \overline{\boldsymbol{a}} \boldsymbol{n}$ 歡 'zadowolona, wesoła, pełna życia';

$\boldsymbol{k} \breve{a} \boldsymbol{i}$ 愷 'wesoła, zadowolona, miła';

lè 樂 'wesoła, zadowolona, radosna';

$\boldsymbol{x} \boldsymbol{\boldsymbol { i }}$ 熙 'wesoła, zadowolona, radosna';

$\boldsymbol{x} \overline{\boldsymbol{i}} \boldsymbol{n}$ 欣 'wesoła, zadowolona, radosna, kochająca';

$\boldsymbol{y} \boldsymbol{i}$ 怡 'wesoła, zadowolona, radosna, miła';

yi 逸 'zadowolona, zrelaksowana';

yù 豫 'zadowolona, usatysfakcjonowana';

$\boldsymbol{y} \boldsymbol{u}$ è 悦 'zadowolona, szczęśliwa, radosna'.

\section{LEKSEMY WYRAŻAJĄCE OGÓLNE WARTOŚCI KOBIET TAKIE JAK FIZYCZNA I DUCHOWA WSPANIAŁOŚĆ, OKAZAŁOŚĆ, POMYŚLNOŚĆ, ŚMIAŁOŚĆ}

Ogółem zakwalifikowano tu 89 leksemów, występujących w 241 imionach ,słynnych kobiet” i 89 imionach ,studentek”, m.in.:

b̆ng 炳 'okazała, błyszcząca';

bó 博 'hojna, bogata';

$\boldsymbol{c a ̆ \boldsymbol { i }}$ 彩 'znakomita, wyróżniająca się, wybitna'; 
càn 燦 'wspaniała, promieniejąca, okazała';

chāng 昌 'wspaniała, kwitnąca, wielka';

dì 大 'wielka, ważna';

fēng 豐 'wielka, obfita, żyzna';

$\boldsymbol{f u}$ 福 'pomyślna, błogosławiona, szczęśliwa';

guăng 廣 'wielka, o otwartym umyśle, kreatywna';

guāng 光 'wybitna, chwalebna';

guì 貴 'godna szacunku, wartościowa';

háo 豪 'śmiała, odważna, mocna';

$\boldsymbol{h}$ 赫 'pomyślna, okazała';

hóng 宏 'wielka, wspaniała';

$\boldsymbol{h} \boldsymbol{u} \overline{\boldsymbol{\imath}}$ 徽 'wspaniała, śmiała, godna szacunku';

$\boldsymbol{h} \boldsymbol{u} \overline{\boldsymbol{t}}$ 輝 'wspaniała, olśniewająca';

ji 吉 'szczęśliwa, pomyślna';

$\boldsymbol{j} \boldsymbol{i} \overline{\boldsymbol{a}}$ 嘉 'znakomita, szczęśliwa';

jiàn 健 'pełna wigoru, zdrowa';

jié 傑 'wybitna, wyróżniająca się, bohaterska';

$\boldsymbol{k} \bar{a} \boldsymbol{n}$ 康 'pełna wigoru, zdrowa, stabilna';

li 力 'silna fizycznie, zdolna';

lóng 隆 'wielka, prosperująca';

qiáng 強 'silna, władcza, prosperująca';

qiáo 喬 'postawna, dorodna, dumna';

quán 權 'potężna, władcza';

róng 榮 'pełna wigoru, okazała, kwitnąca';

ruì 瑞 'szczęśliwa, pomyślna';

shòu 壽 'długowieczna';

$\boldsymbol{w} \overline{\boldsymbol{e}} \boldsymbol{i}$ 威 'potężna, majestatyczna';

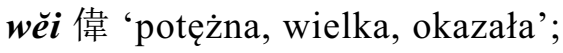

wěi 煒 'okazała, błyszcząca';

xiáng 祥 'szczęśliwa, pomyślna';

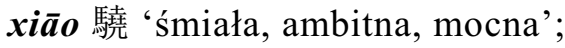

$\boldsymbol{x} \overline{\boldsymbol{n}}$ 金金 'dobrze prosperująca';

$\boldsymbol{x i ̄ n g}$ 興 'okazała, kwitnąca';

xióng 雄 'potężna, władcza';

$\boldsymbol{y} \boldsymbol{e}$ 曄 'okazała, błyszcząca';

$\boldsymbol{y} \boldsymbol{i}$ 益 'dająca zysk, kreatywna';

$\boldsymbol{y} \boldsymbol{i}$ 毅 'mocna, śmiała, rezolutna';

$\boldsymbol{z} \boldsymbol{h} \overline{\boldsymbol{e}}$ 蓁 'okazała, obfita'; 
$\boldsymbol{z h}$ 志 'ambitna, zdeterminowana';

$\boldsymbol{z h} \boldsymbol{\boldsymbol { c }} \overline{\boldsymbol{o}}$ 卓 'wybitna, okazała'.

Łączna liczba leksemów aksjologicznych z grup I-VIII wynosi 283, co daje $27 \%$ wszystkich leksemów z materiału badawczego. Ogólnie wystąpiły one w 1183 imionach „słynnych kobiet” i 417 imionach „studentek”. Wiele wartości w sensie aksjologicznym, ujawniających się w wybranych czy utworzonych odpowiednio imionach, pozostaje w Chinach niezmienionych od tysiącleci. Tym niemniej da się zauważyć, że z imion studentek znikły te typowe terminy żeńskie, które w pewnym stopniu odzwierciedlały niższy status kobiet, ich przedmiotowość, posłuszeństwo i usłużność, a pozostały odwołujące się (bezpośrednio lub metaforycznie) do ich ogólnych walorów estetycznych, intelektualnych, psychicznych i moralnych. W chińskich imionach życzących pojawiają się niemal wyłącznie wartości pozytywne, wartościujące dodatnio.

Przeprowadzone badania zdają się potwierdzać istotną rolę, jaką odgrywają nazwy własne, szczególnie imiona, w rekonstrukcji duchowej kultury społeczeństw. Chińskie imiona życzące, wyrażające wartości kobiet, mają kluczowe znaczenie dla poszerzenia naszej wiedzy o tych kobiecych wartościach psychicznych, moralnych, umysłowych i estetycznych, jakie były i są ważne dla społeczeństwa chińskiego. Poznanie wartości chińskiego społeczeństwa jest korzystne dla dalszych badań w dziedzinie aksjologii.

\section{BIBLIOGRAFIA}

BARTMIŃSKI, JERZY. Językowe podstawy obrazu świata. Lublin: Wydawnictwo UMCS, 2006.

Język w kręgu wartości. Studia semantyczne, red. JERZY BARTMIŃSKI. Lublin: Wydawnictwo UMCS, 2003.

KALETA, Zofia. Human values as reflected in Indo-European compound-names, „Onoma” (Leuven) 34 (1998-1999), s. 83-93.

KalETA, ZofiA. Świat ludzkich wartości odzwierciedlony w nazwach własnych (nazwiska zachodnioeuropejskie i stowiańskie), „Slavia Occidentalis” 52 (1994), s. 28-52.

KALETA, ZofiA. Świat ludzkich wartości odzwierciedlony w nazwach własnych osób (semantyka imion staropolskich z członami -mir, -mysł, -sław na tle indoeuropejskim), „Slavia Occidentalis" 53 (1995), s. 7-13.

KALETA, ZoFIA. Świat ludzkich wartości odzwierciedlony w nazwach własnych osób (Imiona staropolskie z czlonem dobr(o) na tle indoeuropejskim $i$ wartości $w$ nich wyrażone, „Slavia Occidentalis" 54 (1997), s. 29-38. 
Kaleta, Zofia. Values and antivalues in nicknames, w: Proceedings of the 21st International Congress of Onomastic Sciences, 2006, s. 145-155.

KALETA, Zofia. Wartości i antywartości w staropolskich odapelatywnych nazwach osób, w: Nazwy wlasne a kultura, red. Zofia KALETA, (Prace Slawistyczne 115). Warszawa: Slawistyczny Ośrodek Wydawniczy, 2003, s. 21-48.

KAŁUŻYŃSKa, IRENA. Chinese female namings. Past and present. Warszawa: Wydawnictwo Agade, 2008, s. 26-30, 153-161.

KAŁUŻyńSKa, Irena. Semantically transparent given names of the Han nation, w: China Past and Present, red. MARCIN JACOBY [i in.]. Warszawa: WUW, 2010, s. 125-134.

KIANG, KANG-HU. Chinese Civilization. An Introduction to Sinology. Szanghaj: Chung Hwa Book Co., 1935, s. 224-225.

Ku, Hung-Ming. The Spirit of Chinese people. Pekin: The Peking Daily News, 1915.

Liji [,Zapisy o etykiecie”]. Pekin: Shisanjing Zhushu, 1957.

MALEC, MARIA. Imię w polskiej antoponimii i kulturze. Kraków: DWN, 2001, s. 65-97.

PUZYNINA, JADWIGA. Język wartości. Warszawa: Wydawnictwo Naukowe PWN, 1992, s. 19-43.

Rokeach, Milton. The Nature of Human Values. New York: The Free Press, 1973.

RzETELSKA-FeleszKo, EwA. W świecie nazw własnych. Warszawa-Kraków: TNW, 2006.

Zhouli [,,Rytuały Zhou]. Pekin: Shisanjing Zhushu, 1957.

http://pl.wikipedia.org/wiki/Aksjologia

\section{AKSJOLOGIA \\ A CHIŃSKIE TRADYCYJNE IMIONA KOBIET}

Streszczenie

Artykuł omawia grupę tradycyjnych chińskich imion żeńskich zawierających leksemy wskazujące na moralne, psychiczne i behawioralne cechy kobiet. Wspomniane cechy są podobne do wartości ludzkich wyróżnionych przez filozofów i psychologów w dziedzinie aksjologii, czyli teorii wartości. Typologia wartości opracowana przez Miltona Rokeacha w 1973 r. służy jako rama dla prowadzonych badań. Materiał badawczy zawiera 1050 leksemów obecnych w 2931 standardowych imionach własnych chińskich kobiet. Leksemy oznaczające wartości kobiece stanowią $27 \%$ wszystkich analizowanych leksemów, a występują w 1600 imionach. Nazwy własne oznaczające wartości ujawniają $\mathrm{w}$ pewnym stopniu system wartości preferowanych $\mathrm{w}$ tradycyjnych Chinach i wydają się istotne dla dalszych badań w dziedzinie aksjologii.

Słowa kluczowe: aksjologia, wartości instrumentalne, wartości ostateczne, antroponimy, leksemy wyrażające wartości kobiece, chińskie imiona żeńskie.

Key words: axiology, instrumental values, terminal values, anthroponyms, lexemes denoting female values, Chinese female names. 